\title{
GDY OKNO ZABYTKU PRZEMYSŁU STAJE SIE OKNEM MUZEUM - STRESZCZENIE SYTUACJI PRAWNEJ
}

\begin{abstract}
Projektowanie, prowadzenie prac budowlanych i organizacja muzeum w zabytkowych budynkach poprzemysłowych to proces wielowątkowy i skomplikowany. Wymaga też szerokiego kompromisu pomiędzy pragnieniem zachowania historycznej przestrzeni w możliwie niezmienionej formie a chęcią zapewnienia optymalnych warunków samej ekspozycji i ją oglądającym. Jeden z takich dylematów dotyczy problematyki związanej z oknami. Oprócz czynników estetycznych i technicznych ważny bardzo ważny jest aspekt prawny i to na nim skupi się ten artykuł. Przedstawione zostaną w nim najważniejsze akty prawne - nierzadko stojące do siebie w opozycji - wpływające na takie czy inne potraktowanie okien w poprzemysłowych budynkach muzealnych oraz przykłady rozwiązań stosowanych w polskich realizacjach z lat 2004-2015.
\end{abstract}

Słowa kluczowe: okno, zabytek przemysłu, adaptacja, muzeum, prawo

\section{Wprowadzenie}

Obecnie w Polsce przynajmniej dziewięćdziesiąt ${ }^{2}$ obiektów poindustrialnych uległo adaptacji na cele ekspozycyjne, z czego niemal pięćdziesiąt widnieje na liście Narodowego Instytutu Muzealnictwa i Ochrony Zbiorów. Taki stan rzeczy sprawia, że nie sposób mówić o polskiej perspektywie architektury muzealnej w oderwaniu od pojęcia adaptacji zabytku przemysłu. Ciekawą dyskusję na ten temat odnaleźć można w publikacji „Muzeum a zabytek? Konflikt czy harmonia?" [1]. Do rzadkości należą jednak badania konfrontujące teorię z praktyką, dotyczącą konkretnych zagadnień wykonawczych. Część opracowań nie może stanowić aktualnego komentarza chociażby ze względu na datę wydania i mnogość elementów, które od tamtej pory uległy zmianie [2]. Natomiast teksty prasowe, dotyczące polskich muzeów prezentują najczęściej kolejne adaptacje, ale wyraźnie brakuje w nich analiz porównawczych i opisu detali. Konieczne -

\footnotetext{
${ }^{1}$ Marta Rusnak, Katedra Historii Architektury Sztuki i Techniki, Politechnika Wrocławska, ul. Bolesława Prusa 53/55, 50-317 Wrocław, marta.rusnak@pwr.edu.pl

${ }^{2}$ Badania autorki dotyczą publicznych i prywatnych muzeów oraz galerii sztuki
} 
a przynajmniej użyteczne - wydają się skrupulatnego omówienia poszczególnych aspektów towarzyszących praktyce adaptowania przestrzeni poprzemysłowych na cele muzealne i taki też cel przyświeca niniejszemu artykułowi, który koncentruje się na licznych zagadnieniach związanych z oknami.

Artykuł zredagowano w oparciu o polskie przykłady transformacji podjętych w latach 2004-2015. Problem ten, jako dość złożony, został podzielony na dwie części. Pierwszy, prezentowany tutaj fragment dotyczy prawnego kontekstu otworów okiennych w tych obiektach.

\section{Podstawy prawne: jedno okno, trzy ustawy i perspektywy}

Podstawą wszystkich działań architektoniczno-budowlanych jest Prawo Budowlane [3] [4]oraz uzupełniające je rozporządzenia, w tym Rozporządzenie w sprawie warunków technicznych, jakim powinny odpowiadać budynki i ich usytuowanie [5]. Pod względem problemowym są to akty, których głównym celem jest zagwarantowanie bezpieczeństwa użytkowania. Do tej samej grupy przepisów należy włączyć ustawę dotyczącą ochrony przeciwpożarowej [6] oraz przepisy związane z bezpieczeństwem i higieną pracy [7], a także szereg norm i rozporządzeń pomagających $w$ interpretacji tych przepisów. ${ }^{3}$

Drugą wymagającą omówienie perspektywą jest prawna ochrona transformowanego dziedzictwa architektonicznego oparta o ustawę o ochronie zabytków i opiece nad nimi [8]. Twórcy tej ustawy w jasny sposób komunikują, że zachowanie zabytku jest punktem wyjścia dla jej opracowania. Budynek jako zabytek nieruchomy powinien być chroniony w całości, a każdy zachowany historyczny detal ma wspierać podtrzymanie jego autentyzmu.

Trzecią prawną perspektywą, która może mieć wpływ na losy zabytkowego okna w muzeum jest ustawa o muzeach [9]. Główną misją muzeów jest tworzenie jak najlepszych warunków dla zachowania, badań i popularyzacji kolekcji, stąd treść zapisów prawnych została zdeterminowana przez dominującą rolę eksponatu. W celu doprecyzowania zasad ochrony kolekcji wprowadzono rozporządzenie w sprawie zabezpieczania zbiorów muzeum przed pożarem, kradzieżą i innym niebezpieczeństwem grożącym ich zniszczeniem lub utratą [10].

\section{Konflikty wynikające $z$ kolizji wymagań prawnych}

Osobne omawianie wymienionych powyżej ustaw nie wzbudza szczególnie wielkich emocji; do dylematów dochodzi w momencie, gdy rzeczywistość wymaga od projektanta lub przyszłych użytkowników pogodzenia często sprzecznych potrzeb. Dla części zagadnień prawnych droga uzyskiwania odstępstw od reguł projektowych narzuconych przez Prawo Budowlane i towarzyszące mu rozporządznia jest teoretycznie określona. Jednak prawnie jasna procedura nie

\footnotetext{
${ }^{3}$ Ze względu na objętość artykułu nie cytuję tych aktów. Odniesienia do nich można odnaleźć w podanych ustawach
} 
stanowi odpowiedzi na realne konflikty powstające na styku racji opartych o inne kryteria. Poniżej podane zostaną wybrane przykłady starć odmiennych racji i podjęte działania dotyczące zachowania, modyfikacji lub usunięcia zabytkowych okien w obiektach poprzemysłowych przystosowanych dla potrzeb ekspozycyjnych.

\subsection{Zabytek a kryteria architektoniczno-budowlane}

Okna zabytku są jego integralną częścią, którą z perspektywy konserwatorskiej warto zachować. Najczęściej jednak okna fabryk i budynków inżynieryjnych nie spełniają większości warunków technicznych stawianych współczesnym przegrodom budowlanym. Często są to niepielęgnowane przez lata wielko powierzchniowe ustroje o wielu kwaterach wykonanych zazwyczaj z jednej warstwy szklącej. Rozporządzenia powiązane z Prawem Budowlanym określają wysokość parapetu, normy oświetlenia pomieszczeń pracy stałej, powierzchnię otwieranych skrzydeł, czy parametry przeciwpożarowych pasów między kondygnacyjnych gwarantujących ograniczenie rozprzestrzeniania się ognia. Okna dawnych fabryk współcześnie są pod wieloma aspektami rozwiązaniami substandardowymi. Pomimo iż w budynkach zabytkowych istnieje procedura uzyskiwania odstępstw od przepisów, to rzadko udaje się uzyskać taki pakiet odstępstw, który umożliwiałby całkowity brak modyfikacji okien. Stąd ponad $90 \%{ }^{4}$ zabytków o poprzemysłowej tożsamości adaptowanych dla funkcji muzealnych i ekspozycyjnych w latach 2004-2015 ma zmodyfikowane okna. W około $60 \%{ }^{5}$ przypadkach była to zmiana polegająca na usunięciu starych elementów i wykonania nowych.

\subsection{Zabytek ruchomy i nieruchomy w muzeum}

Obie ustawy - o ochronie zabytków i o muzeach - dotyczą zachowania kulturowego dziedzictwa. Pomimo tego ideowego podobieństwa inne cechy zabytków ruchomych i nieruchomych przyczyniają się do powstania niejednego konfliktu. Z tego względu intrygującym fragmentem ustawy o muzeach, który odwołuje się niejako do ustawy o ochronie zabytków, jest ustęp mówiący o zabezpieczaniu przez muzea nieruchomych obiektów kultury materialnej. W ten zbiór niewątpliwie można włączyć zabytkowe siedziby muzeów. Zgodność celów jest jednak pozorna. Wątpliwość budzi sformułowanie o zabezpieczaniu ich przez muzea „w miarę możliwości” (art.2 pkt.4), które stawia zabytek nieruchomy w pozycji gorszej względem muzealiów, które zgodnie z ustawą należy chronić w sposób „trwały”. Ślad tego zróżnicowanego podejścia odnajdziemy w wielu opisywanych w artykule przykładach, w których budynki swobodnie pozbawia się ich oryginalnych detali, aby chronić inne artefakty.

\footnotetext{
${ }^{4}$ Obliczenia autorki

${ }^{5}$ Obliczenia autorki
} 

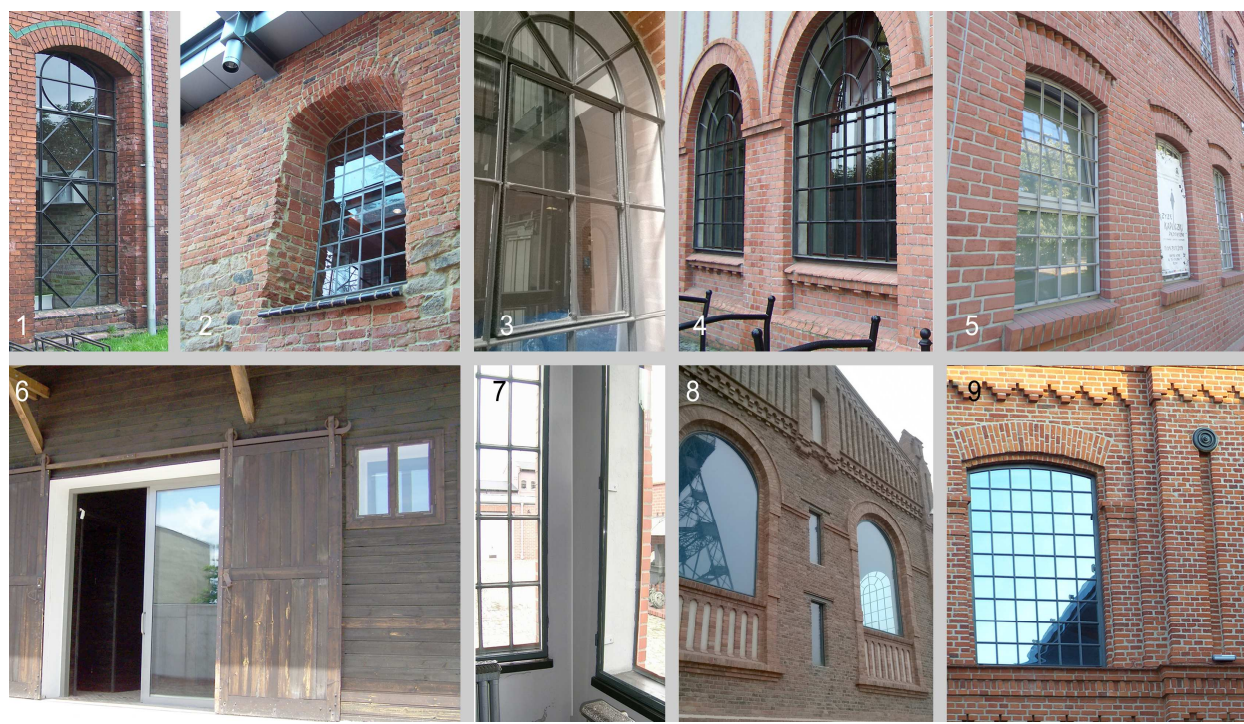

Rys. 1. Okna w umuzealnionych obiektach poprzemysłowych. Zachowana ślusarka (1- 3), ustroje dwuwarstwowe (4-8), nowe okno (9). (Nazwy obiektów i ich lokalizacje: 1.SPOT. w Poznaniu, 2.Tyskie Browarium, 3. Art Inkubator w Łodzi, 4. Muzeum Powstania Warszawskiego, 5. Muzeum Wisły w Tczewie, 6. Stacja Radogoszcz w Łodzi, 7. Muzeum Gazownictwa w Paczkowie, 8. Nowe Muzeum Śląskie, 9. MS2 w Łodzi)

Fig. 1. Windows in postindustrial monuments transformed into museums. Saved windows (1-3), Dabble windows (4-8), new window (9) (Institutions and towns - as above)

\subsection{Termoizolacyjność i mikroklimat wnętrza}

Pośród zagadnień poruszanych przez ustawę o muzeach znajduje się też kwestia zagwarantowania stabilnego mikroklimatu wnętrza: temperatury oraz wilgotności powietrza. Wynika to wprost z (art.2 pkt.3). Dotyczy to zarówno okresu zimowego, gdy zabytkowe okno utrudnia ogrzanie pomieszczeń, jak i okresu lata, gdy intensywne nasłonecznienie wymusza ochładzanie powietrza. Zabytkowe okno znacząco utrudnia kontrolę nad mikroklimatem. Niestety jest to „sytuacja wymagająca odpowiedzialnego wyważenia przeciwstawnych racji” [11]. W efekcie prowadzi to najczęściej do całkowitej wymiany licznych elementów okna, nawet w przypadku gdy nie znajduje się ono w stanie technicznego rozpadu. Warto jednak wspomnieć o tych muzeach, w których podjęto odmienne działania mające na celu choćby częściowe zachowanie oryginału. 


\subsubsection{Zachowanie oryginalnego okna}

W niewielu muzeach zdecydowano się na pozostawienie oryginalnych przeszkleń. Przykładem jest Muzeum Techniki i Włókiennictwa w BielskuBiałej, gdzie przechowywane maszyny tkackie nie należą do grupy szczególnie wrażliwych eksponatów. Stąd pojawiająca się na oknach w zimie para wodna, a w przypadku dużych mrozów nawet przemrożenia nie mają dużego znaczenia. W tym wypadku również pojawiające się pojedyncze nieszczelności nie stanowią dużego zagrożenia przed zanieczyszczeniami chemicznymi mogącymi niszczyć inne grupy eksponatów [11]. Do grupy muzeów z autentycznymi oknami należą też m.in. Walcownia Cynku w Szopienicach i Muzeum Kolejnictwa w Jaworzynie Śląskiej. Są to miejsca, w których muzeum jest kontynuacją tradycji, nie wymusza drastycznych zmian w urbanistyce, bryle czy historycznym detalu.

Miejscami, w których często nie wymienia się, a w miarę możliwości remontuje poprzemysłowe okienna są nierzadko prywatne galerie i centra sztuki. W tej grupie znajdują się: Instytut Sztuki Wyspa w Gdańsku, SPOT w Poznaniu czy Galeria Szyb Wilson w Katowicach. Odmienny sposób do zachowania pierwotnych drzwi i okien pokazano w obrębie Starego Browaru w Poznaniu i mieszczącej się tam siedzibie Art Fundation Grażyny Kulczyk. Pojedyncze stare skrzydła stały się ,eksponatami” umieszczonymi w przestrzeni urbanistycznej lub zawieszone we wnętrzach.

\subsubsection{Wspólistnienie zabytkowego i nowego okna}

Innym spotykanym rozwiązaniem dotyczącym omawianego tematu okna muzealnego w obiekcie poprzemysłowym, jest zdwojenie układu szklenia, w którym na zewnątrz pozostawia się całe oryginalne okno lub jego część, a w niewielkim dystansie dodaje się przegrodę spełniającą współczesne wymagania. Wewnętrzne okno, jako element tła, nie musi już kopiować podziałów oryginalnego okna. Przykład takiego kompromisu można oglądnąć w bydgoskim Explozeum, gdzie zachowano nawet pęknięte pierwotnie zbrojone szyby, w łódzkiej Stacji Radogoszcz, a także w Muzeum Gazownictwa w Paczkowie. Te rozwiązania pod wieloma względami mogą zadowolić i konserwatorów, i przyszłych użytkowników, choć wymagają dodatkowych niestandardowych detali projektowych oraz sprawdzenia fizycznych właściwości całego ustroju w celu uniknięcia niepotrzebnych mostków termicznych, a tym samym stref powierzchniowej kondensacji pary wodnej. Opisany w poprzednich zdaniach zdwojony okienny kompromis konserwatorski zaobserwujemy w Muzeum Powstania Warszawskiego czy Muzeum Wisły w Tczewie. W Warszawie pozbawioną szyb ramę wymontowano przesuwając ją w stronę lica muru, z tyłu zaś zamontowano okna o nowych podziałach. W Tczewie stalowe zabytkowe ramki połączono z ościeżnicą nowego otwieranego okna. 
W adaptowanym budynku maszynowni, gdzie mieści się Nowe Muzeum Śląskie nowe okno wstawiono w miejscu starego, a pozbawione szyb metalowe ramiaki po oczyszczeniu i pomalowaniu zamontowano od środka. We wnętrzu wygląda to korzystnie, tym bardziej, że koresponduje z zachowaną suwnicą i ceramicznymi okładzinami ścian. Od zewnątrz wrażenie jest jednak negatywne. Zły efekt wywołuje niemal lustrzana szyba, która nawet w pochmurny dzień uniemożliwia odczytanie pierwotnych rytmów elewacji. To tylko jeden z przykładów, które obrazują trudności związane z określeniem, która część budynku powinna stanowić konserwatorski priorytet.

\subsection{Ochrona przed promieniowaniem UV}

Kolejnym skutkiem wysokiej ekspozycji solarnej - obok ewentualnego przegrzania - mogą być zniszczenia wywołane promieniami UV, przyspieszającymi przykładowo rozpad włókien celulozy, blaknięcie barwników lub tworzenie się naprężeń w tworzywach sztucznych.

Natężenie promieni ultrafioletowego mogą zmniejszyć odpowiednio dobrane szyby bądź folie używane do zmiany właściwości istniejącego przeszklenia. Decydując się na takie rozwiązanie trzeba jednak pamiętać, że powłoki poważnie wpływają na wygląd elewacji. Przy zastosowaniu wysokich współczynników odbicia można uzyskać wrażenie lustrzanej powierzchni, mogące kłócić się ze stylistyką XIX wiecznego zabytku. Przykładów takich elewacji jest wiele. Do najbardziej wyrazistych należą oddział Muzeum im. Leona Wyczółkowskiego „Czerwony Spichrz” w Bydgoszczy, Muzeum Piernika w Toruniu czy MS2 w Łodzi.

Najprostszym rozwiązaniem, stosowanym w obiektach zabytkowych służącym ochronie eksponatów przed nadmierną insolacją i efektem lustra na elewacji, jest zamontowanie rolet wewnętrznych wykonanych z tkanin o podwyższonej chłonności promieni słonecznych. Przykład takiego rozwiązania zobaczyć można w Muzeum Dawnych Rzemiosł w Żarkach. W innych jednostkach Muzeum Wisły w Tczewie, Centralnym Muzeum Włókiennictwa w Łodzi, Fabryce Schindlera w Krakowie również zastosowano rolety. Niestety ostatecznie nie przełożyło się to na wyeliminowanie, obcej estetyce zabytku, refleksyjności szklenia. Zdaniem autorki równie nienaturalnie wyglądają okna pofabryczne wyposażone w firany i kotary, co zaobserwować można w niektórych salach Muzeum Historii Przemysłu w Opatówku.

Innym rozwiązaniem pozwalającym na uzyskanie nie tylko lepszego mikroklimatu, ale i ochrony przed promieniowaniem UV jest zastosowanie logiki „box in box”, w której elewacja - a więc i zabytkowe okna - stanowi zewnętrzny konserwatorsko zachowany płaszcz dla bardziej zaawansowanego technologicznie wnętrza. W Polsce nie spotkamy jednak tej logiki adaptacji muzealnej. Zagranicznym przykładem jest dawna elektrownia, a obecnie Muzeum Sztuki Współczesnej w Cottbus. 
W zabytku raczej dyskusyjną formą ochrony byłoby zastosowanie ochrony w postaci elementów zewnętrznych: zacieniaczy, banerów czy rolet. Konserwator, pozwalając na inne zewnętrzne transformacje bryłowe, może jednak przyczynić się do zachowania autentyzmu detalu. Miało to miejsce zarówno w łódzkim Art Center, jak i w muzealnej przestrzeni w Browarze w Tychach ${ }^{6}$. W obu przypadkach dobudowane pomiędzy budynkami łączniki sprawiły, że okno z zewnętrznego stało się wewnętrznym i tym samym nie wymagało dodatkowych modyfikacji.

Niezwykle odważną transformacją, $\mathrm{z}$ pewnością nie nastawioną w swoim pierwotnym zamyśle na ochronę przed szkodliwym oddziaływaniem słońca, jest realizacja Muzeum im. Tadeusza Kantora w Krakowie, gdzie nową zawieszoną nad zabytkiem kubaturą niejako „zadaszono” cały stary budynek. Z pewnością ograniczyło to nasłonecznienie wnętrza, choć niestety nie poskutkowało zmniejszeniem refleksyjności szyb.

\subsubsection{Muzeum w zabytku przemysłu bez okien}

Rozporządzenie w sprawie warunków, jakie powinny spełniać budynki i ich usytuowanie dopuszcza oświetlenie pomieszczenia przeznaczonego na pobyt ludzi wyłącznie światłem sztucznym jeżeli oświetlenie naturalne nie jest konieczne lub wskazane ze względów technologicznych. Priorytetem technologii stosowanych w magazynach i salach muzealnych jest zagwarantowanie jak najlepszych warunków dla zachowania eksponatów, przez co korzystne jest wyeliminowanie światła dziennego. Do grupy budynków poprzemysłowych nie posiadających okien lub tylko niewielką ich liczbę należałoby zaliczyć miejsca, w których procedura produkcji narzucała ograniczenie liczby otworów okiennych lub nie wymagała obecności ludzi ${ }^{7}$. Polskimi przykładami są Młyn Wiedzy w Toruniu, Muzeum w Browarze Żywiec oraz wrocławskie Hydropolis. W przypadku tych adaptacji trudno jednak mówić o prawnym kontekście ochrony eksponatów, gdyż ekspozycja w tych atrakcjach turystycznych podąża raczej multimedialnym tropem centrów nauki i rozrywki.

\subsection{Zabezpieczenie przed kradzieżą}

Muzealne okno powinno również zabezpieczać przed kradzieżą. Istnieje kilka sposobów uzyskania tego efektu. Pierwszy można osiągnąć poprzez wymianę szklenia na takie, które cechuje odpowiednio wysoka odporność na włamanie [9]. Pod względem technicznym jest to często niemożliwe, a jeżeli nawet takie szklenie dałoby się wprowadzić, to jest ono bezpodstawne ze względu na wmontowanie jej w zabytkowy ustrój, który nie posiadając żadnych cech prze-

\footnotetext{
${ }^{6}$ Tyskie Browarium i Muzeum Regionalne w Tychach dzielą ze sobą jeden hol

${ }^{7}$ Silosy, zbiorniki gazu, wody, podziemne magazyny, leżakownie czy lodownie
} 
ciwwłamaniowych. Stąd alternatywę stanowi wprowadzenie dodatkowego okna przy zachowaniu okna zabytkowego.

Kolejnym rozwiązaniem jest użycie krat. W wielu wypadkach poprzemysłowe okno ma formę stalowej ramy podzielonej na liczne niewielkich rozmiarów kwatery. W omawianym rozporządzeniu nie podano parametrów, jakie powinna spełniać taka przegroda i jak wygląda wyznaczanie jej geometrii, aby uznać ją za przeciwwłamaniową. Wydaje się, że powinno być to uzależnione od chrakteru i wielkości zgromadzonych eksponatów.

Jeżeli jednak zagęszczenie szczeblin zostaje uznane za niewystarczające ${ }^{8}$, nowa krata powinna jak najmniej wizualnie konkurować z pierwotnymi podziałami na elewacji, stad zarówno ustawa o ochronie zabytków [8], jak i rozporządzenie w sprawie ochrony zbiorów [10], nakazują konsultację z Wojewódzkim Konserwatorem Zabytków. Za przykład wyważonego kompromisu w tej sprawie można uznać rozwiązanie zastosowane we wspomnianej jednostce w Bielsku Białej, gdzie okratowanie wykonano z cienkiej ramki i delikatnej drucianej siatki. Mniej subtelnie wygląda to w Muzeum w Bydgoszczy, choć krata niewątpliwie wygląda solidniej.

\section{Podsumowanie}

Szereg wymienionych powyżej trudności czyni przechowywanie zabytków w zabytku wyborem kontrowersyjnym. Jednak dla wielu obiektów jest to rzadka szansa na przetrwanie, a dla muzealników okazja do powiększenia powierzchni ekspozycyjnych i magazynowych. Dla projektantów i konserwatorów adaptacja zabytku poprzemysłowego na muzeum także jest wielowątkowym wyzwaniem prawnym, w którym zarówno oni jak i inne strony dialogu powinny wykazywać się szeroką znajomością alternatywnych rozwiązań. Ta wiedza powinna ułatwiać podejmowanie większej liczby w pełni świadomych i wyważonych kompromisów. Aby adaptacja muzealna nie była źródłem kolejnych frustracji i niedomówień, dokumenty dotyczące podejmowania kompromisów powinny być upubliczniane, stanowiąc jawne odzwierciedlenie procesu waloryzacji i negocjacji. Cenne byłoby także wdrożenie w program studiów architektonicznych jak największej liczby zajęć pozwalających na interdyscyplinarne spojrzenie na współczesny detal konserwatorski.

\section{Literatura}

[1] Gołubiew Z. (red.), Muzeum a zabytek? Konflikt czy harmonia?, Kraków 2013.

[2] Litwin J., Muzea techniki w Polsce, w: red. Januszewska D.F., Muzea Polskie, Olszanica 2012.

[3] Ustawa z dnia 7 lipca 1994 Prawo Budowlane.

${ }^{8}$ Profile zabytkowych okien, szczególnie drewniane (choć te stanowią mniejszość w omawianych zabytkach techniki) nie zawsze pozwalają na uznanie ich za antywłamaniowe) 
[4] Kiciński A., Światto w muzeum, w: Architekt nr 3/2003.

[5] Rozporządzenie Ministra Infrastruktury z dnia 12 kwietnia 2002 r. w sprawie warunków technicznym jakim powinny odpowiadać budynki i ich usytuowanie.

[6] Ustawa z dnia 24 sierpnia 1991r. o ochronie przeciw pożarowej.

[7] Rozporządzenie Ministra Pracy i Polityki Socjalnej z dnia 26 września 1997 r. w sprawie ogólnych przepisów bezpieczeństwa i higieny pracy.

[8] Ustawa z dnia 23 lipca 2003 r. o ochronie zabytków i opiece nad zabytkami.

[9] Ustawa z dnia 21 listopada 1996 r. o muzeach.

[10] Rozporządzenie Ministra Kultury z dnia 2 września 2014 r. w sprawie zabezpieczania zbiorów muzeum przed pożarem, kradzieżą i innym niebezpieczeństwem grożącym ich zniszczeniem lub utratą.

[11] Łukomski M. (red.), Zarządzanie klimatem w muzeach: ochrona zbiorów i energooszczędność, Ochrona Zbiorów, zeszyt 02, Kraków 2014.

\section{WHEN A WINDOW OF A POSTINDUSTRIAL BUILDING BECOMES A WINDOW OF A MUSEUM - TRANSFORMATION FROM A LEGISLATIVE PERSPECTIVE}

\section{S u m m a r y}

The design, construction and arrangement of a museum in historical postindustrial buildings is a complex, multifaceted process. It often requires a serious compromise between the desire to keep the original building intact and the need to provide both the exhibition and the visitors with the most convenient and suitable conditions. One of such dilemmas is related to the problem of windows. Apart from aesthetic and technical issues, the legal aspect of this transformation is also of great importance and will therefore be the focus point of this paper. This work will present the most important legislative acts - quite often almost contradictory to one another - that govern the treatment of windows in museums and art galleries organized in postindustrial buildings. It will also give examples of different solutions that were applied in Polish investments in the years 2004-2015.

Keywords: window, adaptation, museum, postindustrial buildings, law

DOI: $10.7862 / \mathrm{rb} .2016 .290$

Przestano do redakcji: 22.05.2016 $r$.

Przyjęto do druku: 20.12.2016r. 
